\title{
TRICHINELLA SPIRALIS IN RATS : IN VIVO EFFECTS OF THE BILE AND IN VITRO ACTION OF SECRETORY IgA FROM BILE
}

\author{
E. JACQUELINE*, J. CRINQUETTE**, D. BOUT***, J. BARROIS* et A. VERNES*.
}

SUMMARY. The biliary secretion of rats is diverted from the choledoch duct to the bladder. These rats are resuscitated by sub-cutaneous injections of a salt solution and then infected with Trichinella spiralis larvae. It is shown that the number of adult worms is increased $(+66 \%)$; as is the female larvae production $(+51 \%)$; the females' lenght is also increased $(+25 \%)$.

40 days after the infection the number of muscular larvae is considerably increased $(+79 \%)$ in comparison with control rats.

Secretory IgA (SIgA) from rats bile were tested in vitro on the female production of larvae. This larvae production was more inhibited $(59 \%)$ by immune SIgA than by control SIgA $(25 \%)$.

\section{Trichinella spiralis chez le rat : effets in vivo de la bile et action in vitro des IGA secrétoires de la bile.}

La sécrétion biliaire des rats est dérivée du canal cholédoque dans la vessie. Ces rats sont " réanimés " par des injections sous cutanées d'une solution saline et sont infestés par des larves de Trichinella spiralis. Il est montré que le nombre de vers adultes est augmenté $(+66 \%)$ de même que la production larvaire des femelles $(+51 \%)$; la taille des femelles étant également accrue $(+25 \%) .40$ jours après l'infestation le nombre de larves musculaires est considérablement augmenté $(+79 \%)$ par rapport aux rats témoins.

L'action des IgA secrétoires (SIgA), séparées de la bile des rats et testée in vitro sur la production de larves, est inhibée $(59 \%)$ de façon plus importante par les SIgA immunes que par les SIgA non spécifiques $(25 \%)$.

\section{Introduction}

A previous paper (Jacqueline, Vernes and Biguet, 1978) has shown the in vitro effect of secretory IgA (SIgA) collected in the small intestine of rats and mice, upon the larvae production of Trichinella spiralis. It is now well known (Lemaitre-Coelho,

\footnotetext{
* INSERM Unité 42, Domaine du CERTIA, 369 rue Jules Guesde, 59650 Villeneuve d'Ascq (Directeur J. Biguet).

** Laboratoire de Médecine expérimentale, Faculté de Médecine, Place de Verdun, F 59000 Lille (Directeur F. Guerin).

*** INSERM Unité 167, Institut Pasteur, Boulevard Louis XIV, F 59000 Lille (Directeur A. Capron).

Accepté le 26 février $198 \mathrm{r}$.
} 
Jackson and Vaerman, 1977) that bile contains an important amount of SIgA: from $0.5 \mathrm{up}$ to $0.8 \mathrm{mg} / \mathrm{ml}$ in rats. The purpose of this paper is to outline the experimental, T.spiralis infection of the rat after biliary diversion from the choledoch duct to the bladder according to a technique recently described (Meslin et al., 1978). Thus we show the importance of the bile upon the life cycle of $T$. spiralis and the results are confirmed in vitro by the inhibitory action of bile SIgA on the larvae production.

\section{Materials and methods}

- Rats

Specific pathogen free and three month's old Wistar rats.

- Parasite

T. spiralis strain was obtained in 1970 from the Paris Pasteur Institute and maintained in our laboratory in CBA mice and Wistar rats, Rats were infected orally with $1000 \mathrm{~T}$. spiralis larvae. Recovery of adult parasites and the in vitro determination of female worm fecundity have been described previously (Jacqueline $e t$ al., 1978). The number of larvae present in each rat was determined after pepsin-HCI digestion of skinned, eviscerated carcases, 40 days after the infection (Larsh and Kent, 1949).

- Diversion of rats'biliary secretion

Bile was surgically diverted from the choledoch duct to the bladder as previously described (Meslin et al., 1978). "Diverted" rats lost about $10 \mathrm{~g}$. per day during the first week in spite of enriched food (Meslin et al., 1978); the mortality being high (from 60 to $80 \%$ ). A study of the blood parameters showed an hydro-electrolytic imbalance: a loss of sodium ions (about 15\%) and chiefly an high level of uraemia ( 4 to 5 times the standart value) which was probably the main cause of mortality. Concerning the blood gas the partial pressure of $\mathrm{CO}_{2}$ was increased and correlatively the $\mathrm{pH}$ was low: $7.1-7.2$ instead of 7.4. To restitute the hydro-electrolytic balance of these rats they received three sub-cutaneous injections a week of the following mixture: $20 \mathrm{ml}$ of $0.9 \% \mathrm{NaCl}$ with $13.5 \mathrm{~mm} / 1$ of $\mathrm{NaHCO}_{3}$ and $5.1 \mathrm{~mm} / 1$ of KCI. The result of that process was positive, since the rats recovered their physiological balance and weight; then mortality quite disappeared except for rare surgical shocks (about $5 \%$ ). Control rats had gone through the same manipulations except for diversion of bile and resuscitation. As a whole 50 rats were used to perfect the technique; then rats were infected $48 \mathrm{~h}$ after derivation.

- Measure of females'length

After the in vitro production of newborn larvae, females from "diverted" rats and from control rats were drawn according to examination by a microscope equipped with a camera lucida. The females'length was then noted with a map-measurer. 
- Isolation of SIgA from rats'bile.

Bile was first concentrated by molecular filtration from $30 \mathrm{ml}$ to $8 \mathrm{ml}$ using Amicon filter UM 10. SIgA was separated by chromatography on sephadex G 200 gel (Lemaitre-Coelho, Jackson and Vaerman, 1977) and the SIgA pick was controled by immunodiffusion against rat anti-IgA (Miles Laboratories Inc.) and against whole rat anti-serum, SIgA was concentrated using Amicon filter UM 10 and then lyophilised.

- Statistics

For each series of results we computed the standart deviation, the "compensated t" and thus obtained the value of $\mathrm{P}$ which must be lower than 0.05 to be significant.

\section{Results}

\section{- Consequences of the bile diversion.}

For the first in vivo experiment 12 "diverted" rats were sacrified 5 days after the infection, i.e. 7 days after the bile diversion; in the same time 9 control rats were also studied.

Adults worms were counted, female worm fecundity was tested in vitro and newborn larvae were counted $24 \mathrm{~h}$ later; finally length of female worms was measured. Table 1 shows the results of this experiment. "Diverted" rats presented an increased number of adult worms in comparison with control rats: a mean of $66 \%$.

Female worms from "diverted" rats produced more newborn larvae than those from control rats ( $51 \%$ more) and these female worms presented a significant lengthening in comparison with those from control rats: a mean of $25 \%$.

For the second in vivo experiment 12 other "derived" rats and 6 control rats were keeped 40 days after the infection to account the final consequences of the bile diversion upon the biological cycle of $T$. spiralis, that is to say the number of muscular larvae in rats. In fact (Table I) "diverted" rats presented an increased number of muscular larvae in comparison with control rats: $79 \%$ more.

TABLE I - Consequences of the bile diversion in rats

\begin{tabular}{lcccc}
\hline & Control & $\begin{array}{c}\text { Bile } \\
\text { diverted }\end{array}$ & $\begin{array}{c}\text { Increase } \\
\text { in } \%\end{array}$ & $\begin{array}{c}\text { Statistical } \\
\text { values }\end{array}$ \\
\hline No Adults Worms / Rat & $287 \pm 34$ & $478 \pm 39$ & 66.5 & $0.001<\mathrm{p}<0.01$ \\
No Newborn Larvae / 9 / & $45 \pm 5.3$ & $68 \pm 8.2$ & 51.5 & $0.02<\mathrm{p}<0.05$ \\
$\quad \begin{array}{l}24 \mathrm{H} \\
\text { Length of } \text { P Worms }\end{array}$ & $2.53 \pm 0.07$ & $3.15 \pm 0.05$ & 24.5 & $\mathrm{p}<0.001$ \\
$\quad \begin{array}{l}\text { in mm } \\
\text { No Larvae / g of muscle }\end{array}$ & $170 \pm 5$ & $305 \pm 25$ & 79.2 & $0.001<\mathrm{p}<0.01$ \\
\hline
\end{tabular}


- In vitro action of SIgA from bile.

The results are summarized in Table II. SIgA from control rats bile and from immune rats bile (infected from 7 days: D 7) were tested on the female production of larvae. Thus we showed that the inhibitory action is both nonspecific $(25 \%)$ and specific $(59 \%)$.

TABLE II - In vitro inhibition of the lavvae production by biliary SIgA

\begin{tabular}{|c|c|c|c|c|}
\hline \multirow[t]{2}{*}{$\begin{array}{l}\text { Q. of SIgA } \\
\text { in } 199\end{array}$} & \multicolumn{2}{|c|}{$\begin{array}{l}\text { Mean No Newborn } \\
\text { Larvae / }+ \text { / } 24 \mathrm{H}\end{array}$} & \multirow[t]{2}{*}{$\begin{array}{l}\text { Inhibition } \\
\text { in } \%\end{array}$} & \multirow[t]{2}{*}{$\begin{array}{l}\text { Statistical } \\
\text { values }\end{array}$} \\
\hline & $\begin{array}{l}199 \text { Witl } \\
\text { SIgA }\end{array}$ & $\begin{array}{l}\text { Control } \\
199\end{array}$ & & \\
\hline \multicolumn{5}{|l|}{ - From D.7 Rats } \\
\hline $0.066 \mathrm{mg} / \mathrm{ml}$ & $33.3 \pm 1.9$ & $55.7+4.2$ & 40.2 & $\mathrm{p}<0.001$ \\
\hline $0.133 \mathrm{mg} / \mathrm{ml}$ & $22.7 \pm 2.4$ & $50.1 \pm 4.2$ & 59.2 & $0.001<\mathrm{p}<0.01$ \\
\hline \multicolumn{5}{|l|}{ - From Control } \\
\hline $0.133 \mathrm{mg} / \mathrm{ml}$ & $37.0 \pm 3.8$ & $50.2 \pm 0.3$ & 20.1 & $0.01<\mathrm{p}<0.00$ \\
\hline
\end{tabular}

\section{Discussion}

We previously have described the inhibitory action of SIgA from mice and rats on the in vitro female production of newborn larvae (Jacqueline et al., 1978). This SIgA was collected by washing of the small intestine and thus came both from the bile (Lemaitre-Coehlo, Jackson, and Vaerman, 1977) and from the intestinal mucosae.

The data presented above has shown in vivo that the bile partly controls the quantity and the quality of the successive intestinal stages. Thus the development of the infectious larvae in adults is inhibited by the bile in control rats: 287 adults only per rat against 478 adults per "diverted" rat. In the same way it is interesting to point out the increase of length and fecundity of the female worms issuing from "diverted rats"; this shows that in control rat, the bile seems to inhibit, at least partially, the growth of worms during their intestinal life. Therefore it appears logical to discover much more muscular larvae $(79 \%)$ in "diverted" rats than in control rats, one month later.

The difference obtained between the diverted and undiverted groups at day 5 and the fact that this may be due to specific effects is quite surprising with regard to classical humoral immunological responses; nevertheless it has been shown that local secretory responses are developed faster (Poulain, Pery and Luffau, 1976).

The possible effects of the surgical bile diversion on the worms is to be considered: to avoid as far as possible this influence on the results, control animals have been sham operated. None the less a possible non specific action of bile diversion on the worms cannot be totally excluded.

Nevertheless taking account of the presence of secreting IgA plasma cells in the 
intestinal mucosae, a small amount of SIgA was probably secreted in the small intestine of "diverted" rats; therefore to afford the action of bile SIgA it was necessary to demonstrate their in vitro action.

Our present results fit what we actually know about the immunological aspects of intestinal Nematode infestations. The local antibody production is preeceded by the uptake of the parasite metabolic antigens from the intestinal lumen into villous interepithelial macrophages (Catty, Pritchard and Hankes, 1978). The cells involved in a conventional early antibody response are IgM-containing-cells and later, in the second week of a primary infection, IgG1 and IgA cells are concerned (Grandall, Cebra and Crandall, 1967). During Nippostrongylus brasiliensis infection of rats about 20 per cent of the immunoglobulin-bearing-(B)-cells in the mesenteric lymph nodes bear IgE on their surface on the 14th day (Mayrhofer, Bazin and Gowans, 1976). It is now well known that intestinal mast cells may become sensitized with $\operatorname{IgE}$ antibody and there is correlation between local intestinal mast cells, eosinophils and histamine levels during the "self-cure" phase. Ogilvie and Worms (1976) indicate that antibodies and cells may collaborate to bring about worm expulsion; they propose a two-step expulsion mechanism, the first depending upon the action of antibodies which damage the worms and the second inducing the expulsion depending upon sensitized lymphocytes. Concerning the local cell-mediated response it seems that T-cells may have several indirect influences upon the course of infections of the gastrointestinal tract and mostly a non-specific consequence which is an allergic inflammation unfavourable for parasite survival (Larsh and Weatherly, 1974).

Our work about bile SIgA action take place in the damaging antibodies phase upon the worms before their expulsion.

The quantitatively and qualitatively importance of bile SIgA was recently described.

Concerning the rats'bile, IgA are 10 times more concentrated than in serum (Lemaitre-Coelho, Jackson and Vaerman, 1977) thus the conclusion may be that 10 to $15 \mathrm{mg}$ of SIgA are discharged every day into the duodenum. Authors have proved that the SIgA represent almost all of the total amount of the immunoglobulin secreted in the bile. It has only recently been possible (Fisher et al., 1979) to reveal $0.12 \%$ of SIgM (in comparison with SIgA) but neither $\operatorname{IgG}_{2 a}$ nor $\operatorname{IgE}$ nor monomeric IgA. Orlans et al. (1978) and Jackson et al. (1978) show through different methods that the monomeric IgA of the sera which actively enter the bile, thus become polymeric SIgA provided which a secretory component (S C). On the contrary when rat's choledoch has been ligatured, SIgA and S C can be found free in the serum (LemaitreCoehlo, Jackson and Vaerman, 1978). Furthermore it has been proved (Fisher et al., 1979) that the SIgA are secreted through the association of polymeric IgA and the S C in the liver. Birbeck et al., (1979) prove (using autoradiography and electronic microscope) that it is the hepatocytes which carry the IgA from blood to bile. Finally it seems that serum IgA constitutes an IgA reserve which is ready for local use as early as the first week after infection.

Thus these findings would suggest to us that the inhibitory role of bile in relation to the experimental infection of the rat is both non specific and specific: non specific 
through biliary elements other than immunoglobulins and through SIg (chiefly SIgA) during the first hours of the infection; specific as soon as the SIgA become so.

Our work in progress is attempting to display the exact role of SIgA to show at what moment it becomes specific during a primo-infection and a second-set infection.

Acknowledgments. The authors wish to thank Mme Annie Laspeyres, Mr Didier Deslee and $\mathrm{Mr}$ Gilbert Lepage for their excellent technical assistance.

\section{REFERENCES}

Birbeck M. S. C., Cartwright P., Hall J. C., Orlans E., Peppard J. : The transport by hepatocytes of immunoglobulin A from blood to bile visualized by autoradiography and electron microscopy. Immunology, 1979, 37, 477 .

CATtry D., Pritchard D. I., HANkes J. : Antigen uptake by the small intestine of guinea pigs infected with Trichinella spiralis. Proceedings of the symposium Antigen Uptake by the Gut, Bangor, July, 1975 ed. Hemmings. W.A.M.T.P., Lancaster, 1978.

Crandall R. B., Cebra J. J., Crandall C. A. : The relative proportions of IgG, IgA and IgM containing cells in rabbit tissues during experimental trichinosis. Immunology, 1967, I2, I $47-158$.

Fisher M. M., NAGy B., Bazin H., Underdown B. J. : Biliary transport of IgA : role of secretory component. Proceed. Nat. Acad. Sci., U.S.A., 1979, 76, 2008.

Jackson G. D. F., Lemaitre-Coehlo I., Vaerman J. P., Bazin H., Beckers A. : Rapid disappearance from serum of intravenously infected rat myeloma IgA and its secretion into bile. Europ. J. Immunol., 1978, 8, 123.

JACQUeline E., Vernes A., Biguet J. : Trichinella spiralis : Facteurs immunitaires inhibiteurs de la production de larves. I. Mise en évidence in vivo et in vitro chez la souris. Exp. Parasitol. $1978,45,34$.

JAcQueline E., Vernes A., Bout D., BIguet J. : Trichinella spiralis : facteurs immunitaires inhibiteurs de la production de larves. II. - Première analyse in vitro des facteurs humoraux et secrétoires actifs chez la souris, le rat et le miniporc infestés ou immunisés. Exp. Parasitol., $1978,45,4^{2}$.

LARSH J. E., Kent D. E. : The effect of alcohol on natural and acquired immunity of mice to infection with Trichinella spiralis J. Parasitol., I949, 35, 45-53.

LARSh J. E., WeatherLy N. F. : Cell mediated immunity in certain parasitic infections. Current Topics Microbiol. Immunol., 1974, 67, 113-137.

Lemaitre-Coehlo J., Jackson G. D. F., VAerman J. P. : Rat bile convenient source of secretory IgA and free secretory component. Europ. J. Immunol., I977, 8, 588.

Lemaitre-Coehlo J., Jackson G. D. F., Vaerman J. P. : High levels of secretory IgA and free secretory component in the serum of rats with bile duct obstruction. J. Exp. Med., I978, I47, 934.

MAYRhofer G., BAzIN H., Gowans J. L. : Nature of cells binding anti-IgE in rats immunized with Nippostrongylus brasiliensis : IgE synthesis in regional nodes and concentration in mucosal mast cells. Europ. J. Immunol., 1976, 6, 537-545.

Meslin J. C., Sacouet E., Riotrot M., Leglise P. C. : Effet d'une dérivation de la bile hors du tractus digestif pendant une période prolongée, sur le renouvellement de l'épithélium iléal chez le rat axénique et le rat holoxénique. Annales de Biologie Animale. Biochimie-Biophysique, $1978,18,295$.

Ogrlvie B. M., Worms M. J. : Immunity to nematode parasites. In : immunology of Parasitic Infections ed. Cohen and Sadun E. Blackwell Scientific Publications, Oxford, I976.

Orlans E., Peppard J., Reynolds J., Hall J. : Rapid active transport of immunoglobulin A from blood to bile. J. Exp. Med., (U.S.A.), 1978, r47, 588 .

Poulain J., Pery P., Luffau G. : Nippostrongylus brasiliensis in the rat : Immune response in serum and intestinal secretions. Ann. Immunol., (Institut Pasteur), 1976, I27 C, 209-213. 